\title{
ANALYZING THE IMPACT OF MONETARY POLICY ON FINANCIAL MARKETS IN CHILE
}

\section{ANALISIS DEL IMPACTO DE LA POLITICA MONETARIA SOBRE LOS MERCADOS FINANCIEROS EN CHILE}

\section{ALICIA GARCIA-HERRERO \\ NATIXISand \\ ERIC GIRARDIN \\ Aix-Marseille University (Aix-Marseille School of Economics), CNRS, \& EHESS}

\section{HERMANN GONZALEZ*}

Banco Bilbao Vizcaya Argentaria (BBVA)

\begin{abstract}
During the past few years, monetary policy communication has become a hot topic in as far as it seems to have become a very relevant way for central banks to guide markets, beyond actual monetary policy decisions. This paper investigates this issue empirically for the case of Chile. More specifically, using data from 2005 to 2014 and a Component GARCH model, we assess whether changes in the communication of the Central Bank of Chile generates in particular a permanent or temporary change in the volatility of interest rates, after controlling for changes in monetary policy instruments. Our results show that the volatility in interest rate futures in Chile's swap markets increases following the Central Bank's communication. However, the impact tends to be temporary instead of permanent and only statistically significant in the pre-crisis period. All in all, our results indicate a reduced relevance of Central Bank's communication for short term swap markets which may reflect that market participants have learned to anticipate changes in monetary policy communication, especially after the global financial crisis.
\end{abstract}

Keywords: Monetary policy, communication, interest rates, Chile, Central Bank.

JEL Classification: E52, E58, E43.

* Alicia Garcia Herrero (aligarciaherrero@gmail.com)

Hermann González (hgonzalezb@bbva.com)

Eric Girardin (eric.girardin@univ-amu.fr) 


\section{Resumen}

Durante los últimos años la comunicación de la política monetaria se ha convertido en un tema candente en la medida que ha sido usada por los bancos centrales como una forma muy relevante de guiar a los mercados, más allá de las decisiones de política monetaria. Este trabajo investiga empíricamente el tema para el caso de Chile. Más específicamente, usando datos desde 2005 a 2014 y un modelo C-GARCH, evaluamos si los cambios en la comunicación del Banco Central de Chile generan en particular un cambio permanente o temporal en la volatilidad de las tasas de interés, después de controlar por cambios en los instrumentos de política monetaria. Nuestros resultados muestran que la volatilidad de los futuros de tasas de interés en los mercados de tasas swap de Chile aumenta siguiendo la comunicación del Banco Central. Sin embargo, el impacto tiende a ser temporal en lugar de permanente y solo estadísticamente significativo en el período precrisis. En definitiva, nuestros resultados indican una menor relevancia de la comunicación del Banco Central para los mercados de tasas swap de corto plazo, lo que puede reflejar que los participantes del mercado han aprendido a anticipar los cambios en la comunicación de la política monetaria, especialmente después de la crisis financiera global.

Palabras clave: Política monetaria, comunicación, tasas de interés, Chile, Banco Central.

Classificación JEL: E52, E58, E43.

\section{INTRODUCTION}

In the context of inflation targeting regimes like the one which has been in place in Chile since 1991, a transparent and credible communication is a key element to ensure the effectiveness of monetary policy. Monetary policy will be considered effective whenever it is able to align the expectations reflected by market interest rates with the vision of the Central Bank about the key interest rates within the horizon of the monetary policy.

The objective of this paper is to assess empirically whether interest rate futures in Chile (swap rates) react to changes in the monetary policy rate (MPR) and, especially, to different pieces of communication released by the Central Bank of Chile (CBC). We use daily data from 2005 to 2014, quantifying communication in line with Rosa and Vega (2007) and building on a Component GARCH model (Ding and Granger, 1996; Engle and Lee, 1999) that allows us to determine whether changes in monetary policy instruments and communication generate a permanent or temporary change in the volatility of interest rate futures.

The relevant Chilean literature has mostly revolved around two aspects of monetary policy and its effects on markets. One strand of the literature has highlighted the importance of credibility and transparency of monetary policy, both in terms of 
effectiveness as well as in terms of the legitimacy of the Central Bank as independent agency. The second strand of the literature aims at quantifying the impact of monetary policy surprises on market interest rates. The evidence regarding the effects of monetary policy communication on the level and volatility of short term interest rates is weak or inexistent. Our analysis corresponds to this second strand but focuses on the impact on the short end of the curve.

The effectiveness of monetary policy depends both on the credibility the Central Bank enjoys and on the transparency of its communication. Regarding the first point, Céspedes and Soto (2006) suggest that when the CBC was gaining credibility, price adjustments occurred less frequently, the weight assigned to the inflation target in the mechanism of indexation increased at the expense of past inflation, and the impact of the exchange rate on inflation faded. Furthermore, these results imply that the changes in the inflation process could have had an important impact on the conduct of monetary policy. In particular, by gaining credibility, the Central Bank was able to counter deviations in inflation from the target more vigorously without having to considerably sacrifice GDP.

De Gregorio (2008) suggested that the transparency of the conduct of monetary policy by an autonomous Central Bank is fundamental, not only for reasons of effectiveness, but also as a necessary measure of legitimacy that an independent institution in a democratic system should possess. Moreover, he states that conducting monetary policy with an inflation target of $3 \%$ projected for two years, requires permanently high levels of transparency and a clear communication of the evaluation of the economic situation and of the objectives pursued by the Central Bank. However, he indicates that transparency should be limited in order to avoid jeopardizing the achievement of price stability. Also Vergara (2014) states that Central Bank communication policies have changed over the last decades, due to the fact that central banks realized that monetary policy works better when it is open and transparent. In addition, a greater degree of transparency and openness protects them from political pressures.

With regard to the effects of monetary policy on market interest rates, the studies of Meyer (2006) and Larraín (2007) analyze the impact of unexpected monetary policy rate (MPR) changes on interest rates on medium and long term securities issued by the Central Bank. The study of Meyer focuses on the response of the Central Bank bonds denominated in pesos (BCP) and $\mathrm{UF}^{1}(\mathrm{BCU})$ to economic announcements, including surprises in the MPR. Differing from the study of Larraín who used forward rates in order to quantify market expectations concerning the MPR, Meyer uses the Bloomberg survey. The results of his study indicate that the return on nominal instruments with a maturity of 5 years (BCP-5) rises roughly by $6.5 \mathrm{bp}$ (basis points) when facing an unexpected increase of $25 \mathrm{bp}$ of the MPR. The interest rates of the instruments denominated in UF with maturities of 5 and 10 years also tend to move in the same direction facing an unexpected change in the MPR. When confronted with an unexpected movement of the MPR of $25 \mathrm{bp}$, the BCU-5 and BCU-10 bills move by around 6.4 and $5.1 \mathrm{bp}$, respectively.

1 Unidad de Fomento: Unit of measure linked to the inflation rate. 
The study of Larraín (2007) estimates the impact of innovations of monetary policy on the nominal and real yield curve in Chile during the period from 2002 to 2007. His paper documents that a monetary policy surprise has a positive and significant impact on the nominal yield curve. An increase of 100 basis points of the MPR, in turn, increases the one-year interest rate by 35 basis points. However, this effect decreases with maturity, ending in an effect of $13 \mathrm{bp}$ on the 10 -year interest rate. At the same time, the observed effects of an innovation in the monetary policy on the real yield curve are minor and the expected component of the monetary policy does not have a significant impact on the yield curve.

This study contains many innovative features related to the effects of monetary policy and monetary policy communication on market rates in Chile. First, it constructs an exhaustive measure of CBC's communication covering written statements from 2005 to 2014, indicating whether the monetary authority is willing to tighten, maintain unchanged or ease monetary conditions (i.e. whether the pieces of communication are contractionary, neutral or expansionary). Importantly, our measure includes all written statements (communiqués of the monetary policy decisions, monetary policy meetings' minutes and quarterly inflation reports). This is in contrast with studies that only consider surprises in the MPR decisions and not the tone of the communication. Second, for the first time in the literature on Chile, we consider whether communication impacts volatility temporarily or permanently, thanks to the use of a componentGARCH model (a la Ding and Granger, 1996; and Engle and Lee, 1999). We are thus able to show that the impact is always only temporary and after Lehman no more statistically significant on both maturities considered (180 and 360 days). As our analysis also takes the impact on volatility into account, among other things (i.e. the monetary policy communication tone), we provide a more complete characterization of these changes than that provided by previous work (Meyer 2006 and Larraín 2007).

We show that in general swap rates increase (decrease) following a rise (fall) in the reference rate. Moreover, the volatility in swap rates rises (decreases) after the release of a piece of "contractionary" ("expansionary") communication by the CBC, although the effect is only temporary and no more statistically significant in the post crisis period. Our analysis also reveals that the impact of monetary policy changed significantly after the 2008 crisis. The effects of changes in MPR on the changes in swap rates increased and at the same time the communication process became less noisy (i.e. the impact on the level and volatility of swap rates became smaller).

The paper is structured as follows. Section 2 presents the methodology as well as the data compilation, with particular attention to the construction of our measure of CBC communication, including the $\mathrm{CBC}$ documents it builds on. Section 3 provides our empirical results and interpretations, including some robustness analysis. Finally, Section 4 draws some conclusions.

\section{DATA AND METHODOLOGY}

\subsection{Data}

In the context of the inflation targeting scheme which has been in place since 1991, the CBC has taken relevant steps towards a clearer communication about the 
economic scenario and the monetary policy decisions. The Central Bank Board is in charge of setting the monetary policy and defining the reference interest rate (MPR). The Board meets to determine the MPR once a month. On the eve of the meeting, background material prepared by the staff is posted on the Central Bank's web site; the day of the meeting a communiqué is published at $6 \mathrm{PM}$; the next day, the graphs and tables used in the monetary policy discussion are also posted on the Central Bank's web site and finally, two weeks after the meeting, the minutes are made public.

The main information vehicle used to communicate the Central Bank macroeconomic forecasts and monetary policy assumptions is the quarterly Monetary Policy Report (IPoM). Additionally, there are other publications employed by the Central Bank's Board in order to announce its vision of the current developments of the economy and the perspectives of inflation; these are the communiqués and minutes of the monthly monetary policy meetings, the presentations and speeches of the Board members and the interviews conducted by various press agencies. Moreover, all public information is published on the webpage of the Central Bank. With the purpose to act as independently as possible during the monetary policy meetings and minimize the risk to produce disruptions in the financial markets, the Board of the Central Bank has imposed a period of silence on itself covering the days before meetings and the release of the IPoM.

For the purpose of constructing a measure of CBC communication we take into account three pieces of communication as financial markets are potentially impacted by each one of them. These are the quarterly inflation reports, the monthly communiqués and the minutes of the monetary policy meetings. Therefore, we include in our sample the 118 communiqués, the 118 minutes and the 35 inflation reports released from January $11^{\text {th }} 2005$ to October $16^{\text {th }} 2014$.

We follow Rosa and Vega (2007) and codify the available CBC communication to get an index ranging from -2 to +2 , i.e. indicating whether there is a very clear intention to loosen monetary policy ahead ("very expansionary" tone: -2 ), just some intention to loosen monetary policy ("expansionary" tone: -1 ), the intention to maintain monetary conditions unchanged ("neutral" tone: 0 ), some intention to tighten monetary policy ("contractionary" tone: +1 ) or a very clear intention to tighten monetary policy ahead ("very contractionary" tone: +2 ).

Table 1 presents some examples of pieces of communication released by the $\mathrm{CBC}$, together with the code attached to it, and Figure 1 displays a time series of the communication index used in our estimations.

\section{Financial markets: futures interest rates}

Different from the scarce existing literature about monetary policy's impact on long term interest rates, we focus on the effect on 180- and 360-day swaps rates (SPC). Movements in those rates are plotted in Figure 2. The swaps rates market has grown substantially since 2002, so the information obtained from SPC is increasingly representative of market expectations.

In Chile swaps rates operations in national currency are made in Chilean pesos and in UF and the data is available at the CBC web page. Users of SPC are the major banks that operate in the local market, which employ those instruments to make risk 


\section{TABLE 1}

EXAMPLES OF BC COMMUNICATION AND ATTACHED CODE

\begin{tabular}{|c|c|c|c|}
\hline Code & Meaning & $\begin{array}{l}\text { Example of } \\
\text { communication }\end{array}$ & Excerpts \\
\hline 2 & $\begin{array}{l}\text { Very } \\
\text { contractionary }\end{array}$ & $\begin{array}{l}\text { Minutes } \\
\text { (August 29, 2008) }\end{array}$ & $\begin{array}{l}\text { The most credible and prudent decision was to } \\
\text { mantain the rhythm of strong MPR hikes; the } \\
\text { process of monetary adjustment has not been } \\
\text { cocluded and the most probable scenario was that } \\
\text { the MPR would need to be revised to a higher } \\
\text { level in the upcoming months. }\end{array}$ \\
\hline 1 & Contractionary & $\begin{array}{l}\text { Communiqué } \\
\text { (April 12, 2011) }\end{array}$ & $\begin{array}{l}\text { It will be necessary to continue on with the reduction } \\
\text { of the monetary stimulus in the coming months. }\end{array}$ \\
\hline 0 & Neutral & $\begin{array}{l}\text { Minutes } \\
\text { (October 3, 2014) }\end{array}$ & $\begin{array}{l}\text { The MPR was situated at a perfectly reasonable } \\
\text { level, moreover it is important to concretize that } \\
\text { this cycle of decreases have been concluded. }\end{array}$ \\
\hline-1 & Expansionary & $\begin{array}{l}\text { Communiqué } \\
\text { (April 17, 2014) }\end{array}$ & $\begin{array}{l}\text { The possibility to introduce additional MPR cuts } \\
\text { in accordance with the development of relevant } \\
\text { internal and external macroeconomic decisions } \\
\text { will be evaluated. }\end{array}$ \\
\hline-2 & $\begin{array}{l}\text { Very } \\
\text { expansionary }\end{array}$ & $\begin{array}{l}\text { Minutes } \\
\text { (February 5,2009) }\end{array}$ & $\begin{array}{l}\text { A strong reduction of the MPR ahould be followed } \\
\text { up by further strong reductions since this cut is just } \\
\text { a part of the total reduction required and therefore } \\
\text { one should expect significant movements in the } \\
\text { next months. }\end{array}$ \\
\hline
\end{tabular}

\section{FIGURE 1}

CBC COMMUNICATION INDEX

(Ranging from -2 to +2 from Jan $11^{\text {th }} 2005$ to October $16^{\text {th }} 2014$ )

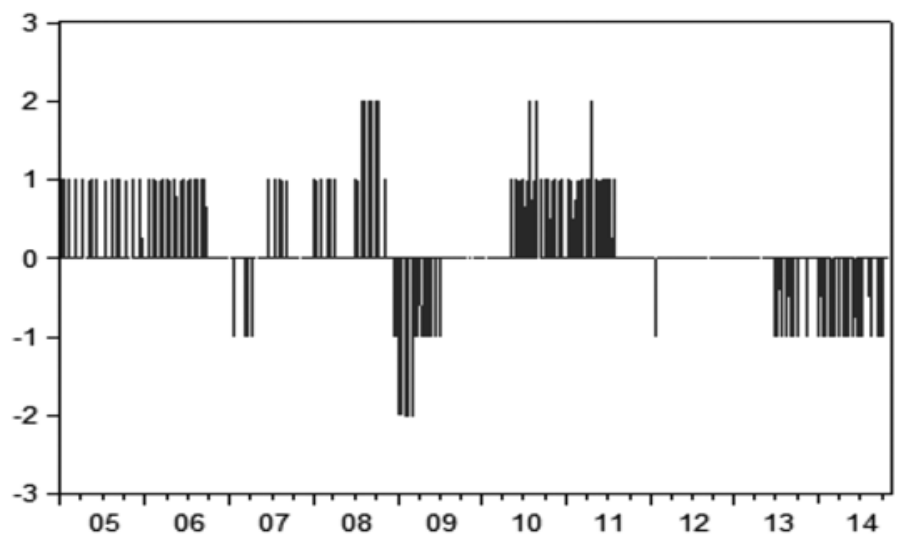




\section{FIGURE 2}

“SWAP PRE X DI" FIXED-RATE SWAPS RATES, 180 AND 360 DAYS (\%)

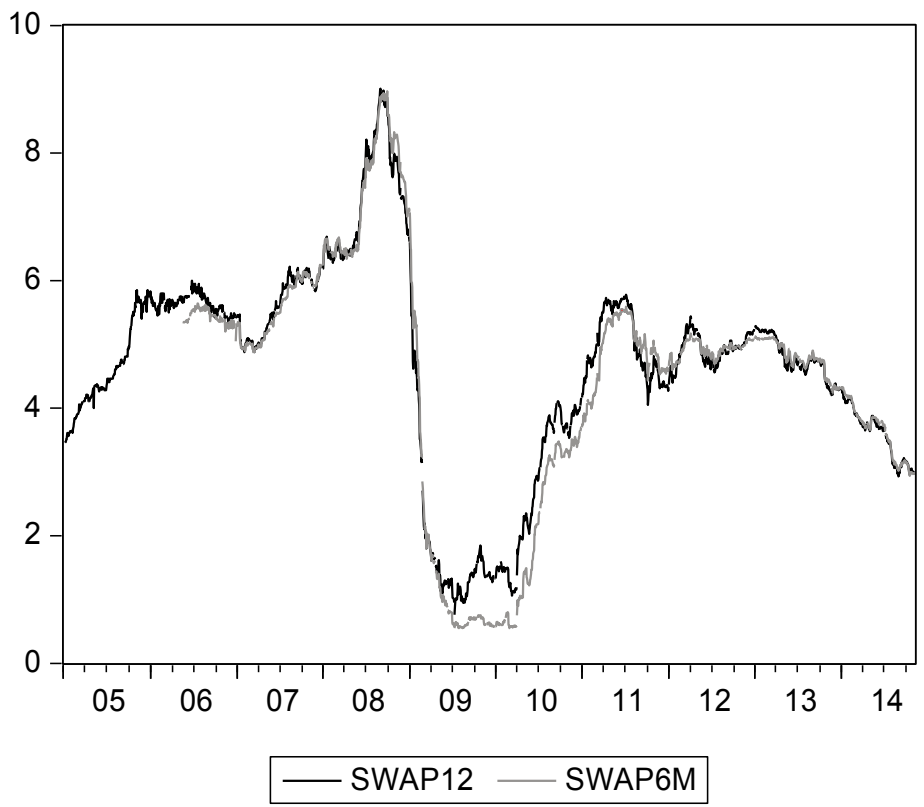

Source: Bloomberg.

coverage operations and speculate. Also some foreign institutions, like banks and hedge funds, primarily from the US, operate SPC with national banks. The main maturities traded, both in pesos and in UF, are six months, one year, and two years.

We focus the analysis in 180 and 360 day swaps rates, because it is of our interest to study the effects of monetary policy decisions and communication on short term interest rates. Following the work made by Garcia-Herrero, Girardin and Dos Santos (2015) for Brazil, the short term market is better represented by maturities until one year. Another reason is that in the case of Chile the two-year swap market tends to be less liquid than the 180 and 360 day ones.

\section{Monetary Policy Rate and other macroeconomic variables}

The change in SPC rates $^{2}$, our financial variables of interest, will be the independent variables in our econometric exercises. In addition to our $\mathrm{CBC}$ communication index,

2 Descriptive statistics are presented in Appendix 1. 
which is our main explanatory variable, we will include, as controls, the change in monetary policy rate (MPR) set by the CBC Board during its monetary policy meetings (see Figure 3), the change in global risk aversion proxied by the VIX, and the change in US dollar interest rate swap rate to control for changes in the US monetary policy stance (see the sub-section on methodology below for more details).

\subsection{Methodology}

To evaluate the impact of CBC communication on Chile's interest rate futures, we adopt an encompassing approach in the spirit of Ehrmann and Fratzscher (2007), using joint estimates of the mean and the volatility of interest rate futures. Regarding the first, we analyze empirically whether swap markets understand CBC's words. Following Ehrmann and Fratzscher (2007), we examine whether speeches and written statements move mean interest rate changes in the intended direction, i.e. as indicated by our CBC communication index. With respect to the volatility, we follow Kohn and Sack (2004), Connolly and Kohler (2004) and Reeves and Sawicki (2007). In

\section{FIGURE 3}

MONETARY POLICY INTEREST RATE SET BY THE MPC (\%)

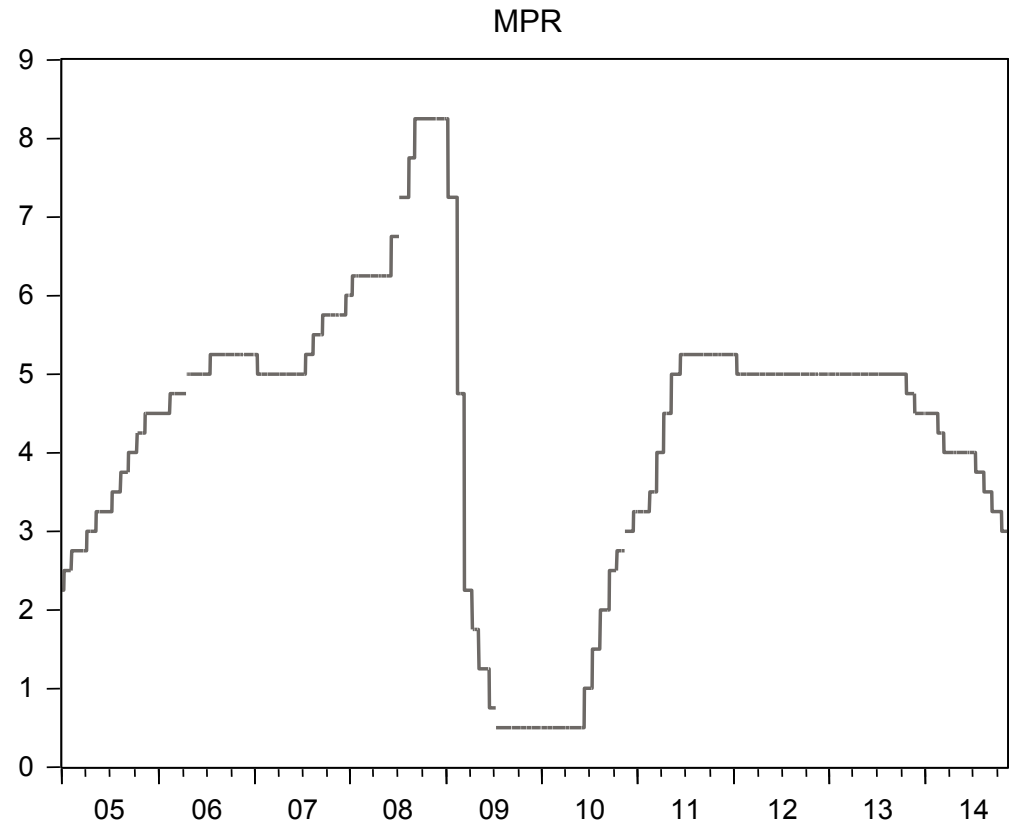

Source: Central Bank of Chile. 
principle, the most logical hypothesis is that the volatility of asset returns should be higher on days of Central Bank communication, everything else equal, because such signals contain news. However, a reduction in volatility could also be a response to central-bank communication in as far as the situation prior to such news was very uncertain, in such a way that it helps calm down the market (Geraats, 2002).

The model is, thus, composed of two different parts. On the one hand, equation (1) analyses how Central Bank's communication affects the mean interest rates. On the other hand, equations (2) and (3) specify the volatility of the change in the swap rate and how Central Bank communication may affect it. To that end, it uses a conditional volatility model, namely a component-GARCH model (to be explained below), as suggested by Garcia-Herrero, Girardin and dos Santos (2015) for the study of the effects of monetary policy communication.

We make the change in futures interest rate (SWP in our notation below) depend on the Central Bank's communication variable (COM), as well as on other relevant controls. In the volatility part of the analysis, the absolute value of the communication variable (ACOM) replaces the $\mathrm{CBC}$ communication variable. Such communication variables enter the equations at time $t$. The control variables include, most importantly, the change in the stance of monetary policy, i.e. the observed daily change in the policy rate $(\Delta \mathrm{PR})$, or the surprise component in that change (Realized minus expected). Finally, we control for the well-known global risk aversion, proxied by the VIX in first difference (since the level of this variable is non stationary), as well as the (one-year) US dollar interest rate swap rate, to control for changes in the US monetary policy stance.

It is important to determine whether communication has persistent or temporary effects, i.e. whether it impacts long-run or short-run volatility. We employ the componentGARCH(C-GARCH) model of Engle and Lee (1999) and Ding and Granger (1996) in order to be able to do precisely this. The encompassing model is a C-GARCH model for the swap interest rate of maturity $j$ as follows, with mean equation (1) and volatility equations (2) and (3):

$$
\begin{aligned}
& \begin{array}{c}
\Delta S W P_{j t}=a_{1}+\sum_{k=1}^{n} a_{2 \mathrm{k}} \Delta S W P_{j t-j}+a_{3} C O M_{t}+a_{4}(\Delta P R)_{t}+a_{5} \Delta V I X_{t} \\
+a_{6} \Delta U S S W A P+\left(h_{t}\right)^{1 / 2} v_{t}
\end{array} \\
& \left(q_{t}\right)=\omega+\rho\left(q_{t-1}-\omega\right)+\phi\left[\left(\varepsilon_{t-1}\right)^{2}-h_{t-1}\right]+\lambda \text { ACOM }_{t} \\
& \left(h_{t}-q_{t}\right)=\alpha\left[\left(\varepsilon_{t-1}\right)^{2}-q_{t-1}\right]+\beta\left[h_{t-1}-q_{t-1}\right]+\mu \text { ACOM }_{t}
\end{aligned}
$$

The time-varying variance of the change ${ }^{3}$ in the swap rate is noted as $h_{t}$, and $\varepsilon_{t}$ is a unit-variance, serially uncorrelated, zero mean, i.i.d. error term. In addition, $q$

3 We model the first difference in the swap rates in light of the presence of a unit-root in their level as reported in Appendix 1. 
represents the long run component of volatility, which converges to the long-run timeinvariant volatility level $\omega$ according to the magnitude of $\rho$. Equation (3) specifies the short-run dynamics, in which volatility moves around this long-run time-varying mean. Accordingly, the deviation of the current conditional variance from the longrun variance at time $t$ is affected by the deviation of the previous error from such long-run variance and the previous deviation of the conditional variance from the long-run variance $q$. It is noteworthy that the short run component can be either positive or negative, since volatility fluctuates around the long run component. Due to non-normality in the residuals we use the Student-t distribution.

We estimate restricted versions of this model in two separated steps. On the one hand, we examine whether markets understand the $\mathrm{CBC}$ by excluding the absolute value of the communication variable (ACOM) from the conditional variance equation $(\mu=\lambda=0$ in equations (2) and (3)). On the other hand, we test whether the volatility of interest rates reacts to the $\mathrm{CBC}$ words, by excluding the communication variable from the mean equation $\left(a_{3}=0\right.$ in equation (1)). On the basis of the likelihood, we test whether communication influences rather the long run ( $\lambda$ different from zero) or the short run ( $\mu$ different from zero) component of volatility.

\section{EFFECTS OF CBC COMMUNICATION ON INTEREST RATE SWAP MARKETS}

In this section we show the results of our estimations that measure the effects of the MPR and, more importantly given this paper's objectives, the impact of communication on the volatility and the mean of swap rates changes.

We focus our analysis on two periods, the first from May 2006 until September 2008, the "pre-crisis period", and the second, from February 2009 until November 2014, the "post-crisis period". The division of the sample in two sub-periods is in line with the general perception and the evidence already presented by the literature that the global financial crisis structurally changed, among many other things, the management and the impact of monetary policy.

\subsection{Do changes in the MPR impacts changes in SPC rates?}

From the estimation of equation (1), leaving parameter $a_{3}$ free (but constraining $\lambda=$ $\mu=0$ ), we are able to get an estimate for the parameter $a_{4}$, which measures the impact of changes in the traditional monetary policy instrument, i.e. the MPR, on swap rates. The Table 2 shows that, only in the post-crisis period, this effect of monetary policy is positive and significant for both maturities considered. This means that increases (decreases) in the MPR have been driving swap rates up (down), as expected, but only since 2009. In the pre-crisis period, the impact of changes in the MPR on swap rates was not statistically significant for the 180-day maturity and only marginally significant for 360 days. 
TABLE 2

EFFECT OF CHANGES IN MONETARY POLICY RATE ON DAILY CHANGES IN SWAP RATES

\begin{tabular}{|c|c|c|}
\hline $\begin{array}{l}\text { Swap rate changes } \\
\text { (maturity) }\end{array}$ & $\begin{array}{c}\text { Pre-crisis: } \\
\text { May 24, } 2006 \text { - September 12, } 2008\end{array}$ & $\begin{array}{c}\text { Post-crisis: } \\
\text { February 2, } 2009 \text { - November 3, } \\
2014 \\
\end{array}$ \\
\hline $\begin{array}{l}180 \text { days } \\
360 \text { days }\end{array}$ & $\begin{array}{r}0.016 \\
-0.07 *\end{array}$ & $\begin{array}{l}0.034 * * * \\
0.040 * *\end{array}$ \\
\hline
\end{tabular}

Interest rate swap rate: Daily close minus previous day close. Component-GARCH estimation with Student-t Distribution. This corresponds to the estimation of equation (1) jointly with (2) and (3) with $\lambda=\mu=0$. The coefficients of control variables are reported in Appendix 2 Table 2.1. *** significant at the 1\% (** $5 \% ; * 10 \%$ ) on the basis of the Z-statistics.

\subsection{Does CBC communication impact changes of interest rate futures?}

From the estimation of equation (1) we also obtain an evaluation of the impact of the variable constructed to summarize the directional intent and intensity of communication on swap rates. We find that in the pre-crisis period the swap rates react to the communication by the $\mathrm{CBC}$ in the intended direction, i.e. they increase (decrease) following contractionary (expansionary) pieces of communication. Nonetheless, in the post-crisis period this impact is no more significant.

That is, combining the results so far, we see that, in the post-crisis period, monetary policy decisions, measured by their impact on swap rates, have gained prominence over the communication itself.

TABLE 3

EFFECT OF CBC COMMUNICATION ON DAILY CHANGES IN SWAP RATES

\begin{tabular}{|c|c|c|}
\hline $\begin{array}{c}\text { Swap rate changes } \\
\text { (maturity) }\end{array}$ & May 24, 2005 - September 12, 2008 & $\begin{array}{c}\text { Post-crisis: } \\
\text { February 2, 2009- November 3, } \\
2014\end{array}$ \\
\hline 180 days & $0.020 * * *$ & -0.0015 \\
360 days & $0.034 * * *$ & -0.0027 \\
\hline
\end{tabular}

Daily close minus previous-day close. The COM dummy for communication has a FIVE-pronged classification as very expansionary $(-2)$, expansionary $(-1)$, neutral $(0)$, contractionary $(+1)$, and very contractionary (+2). Component-GARCH estimation with Student-t Distribution. This corresponds to the estimation of equation (1) jointly with (2) and (3) with $\lambda=\mu=0$. The coefficients of control variables are reported in Appendix 2 Table A.2.1. $* * *$ significant at the $1 \%(* * 5 \%$; $* 10 \%)$ on the basis of the Z-statistics. 


\subsection{Does CBC communication impact the volatility of interest rate futures?}

Leaving $\lambda$ or $\mu$ free in equations (2) and (3), but constraining $a_{3}$ to zero in equation (1), we test the hypothesis that volatility of swap rates moves in a statistically significant way right after the release of $\mathrm{CBC}$ communication.

As far as the expected sign is concerned, existing literature has long preferred to rationalize increases in volatility in response to communication as a confirmation that markets listen to Central Bank's communication. The underlying justification was that messages from central bankers convey new information and that the latter tends to move markets.

Another view would rather interpret a fall in volatility as an indication that Central Bank communication is able to calm markets. The explanation of the latter phenomenon, suggested by Geraats (2002), relies on the presence of a degree of uncertainty before the Central Bank speaks and also the clarity of its speech. In her view, central banks may as well confuse markets (increasing volatility) as clarify the situation (reducing it). The novelty of our analysis consists in ascertaining whether such an impact on volatility is transitory or persistent.

Results in Table 4 indicate that, for both maturities, the volatility in swap markets increases following the release of $\mathrm{CBC}$ communication, indicating that the $\mathrm{CBC}$ words convey information that markets perceive as relevant. This is in line with Fleming and Remolona (1999) and Ehrmann and Fratzscher (2007). However, also in this case, the impact of the CBC communication on financial markets' volatility is only statistically significant in the pre-crisis period, confirming the finding that in the post-crisis period the CBC communication became less noisy.

In addition, the component-GARCH model enables us to observe that before and after the crisis the impact of communication on the variance of swap rate changes was temporary in both cases (i.e. on the 180 and the 360-days maturities) since we never found any significant effect on long run volatility (i.e. the coefficient $\lambda$ is always insignificant in equation (2)).

\section{TABLE 4}

EFFECT OF CBC COMMUNICATION ON VOLATILITY OF CHANGES IN SWAP RATES

\begin{tabular}{|c|c|c|}
\hline $\begin{array}{l}\text { Swap rate } \\
\text { maturity }\end{array}$ & $\begin{array}{c}\text { Pre-crisis: } \\
\text { May 24, } 2005 \text { - September 12, } 2008\end{array}$ & $\begin{array}{c}\text { Post-crisis: } \\
\text { February } 2,2009 \text { - November 3, } \\
2014\end{array}$ \\
\hline $\begin{array}{l}180 \text { days } \\
360 \text { days }\end{array}$ & $\begin{array}{l}\text { T0.0021** } \\
\text { T0.0061** }\end{array}$ & $\begin{array}{l}\text { T0.00053 } \\
\text { T0.0002 }\end{array}$ \\
\hline
\end{tabular}

This corresponds to the coefficient of ACOM in equation (3) for the temporary (T) component, estimated jointly with equations (1) and (2). We report the coefficients of control variables in Appendix 2, Table A.2.2.1. The table presents the coefficient of the absolute value of the dummy for coded statements. The ACOM dummy takes a value of one when a statement occurs and zero when there is none. ComponentGARCH estimation with Student-t Distribution. *** significant at the $1 \%(* * 5 ; * 10 \%)$ on the basis of the Z-statistics. In each cell in this table, T stands for temporary effects. (a) P-value: 0.14 . 


\subsection{Robustness analysis}

One could argue that we should focus on the impact of a surprise change in the MPR rather than in the actual change in interest rates. Accordingly, we re-estimate our mean model ${ }^{4}$ substituting the observed change in the MPR for the unexpected change of the policy rate in equation (1). As shown in Table 5, by considering surprise changes in MPR rate we confirm that the impact of deeds was statistically significant only in the post-crisis period. In quantitative terms the effect of surprise changes in MPR on swap rates is greater than that of the effective changes in MPR; up to two or three times greater, depending on the maturity of the swap rate considered. Such a difference in magnitude is logical in as much as expected policy changes should already have been taken into account by forward-looking markets.

\section{TABLE 5}

\section{EFFECT OF SURPRISE CHANGES IN MONETARY POLICY RATE ON DAILY CHANGES IN SWAP RATES}

\begin{tabular}{|c|c|c|}
\hline $\begin{array}{c}\text { Swap rate changes } \\
\text { (maturity) }\end{array}$ & $\begin{array}{c}\text { Pre-crisis: } \\
\text { May 24, 2005 - September 12, 2008 }\end{array}$ & $\begin{array}{c}\text { Post-crisis: } \\
\text { February 2, 2009 - November 3, } \\
2014\end{array}$ \\
\hline 180 days & -0.011 & 0.040 \\
360 days & -0.035 & $0.109 * * *$ \\
\hline
\end{tabular}

The Surprise variable is observed minus expected MPR rate in equation (1). Component-GARCH estimation with Student-t Distribution. This corresponds to the estimation of equation (1) jointly with (2) and (3). $* * *$ significant at the $1 \%(* * 5 \% ; * 10 \%)$ on the basis of the Z-statistics.

Controlling for surprise MPR changes, the impact of communication on the level of swap rates (Table 6) is similar to that displayed previously in Table 3. This implies that, in line with the results found in other studies for the US and Brazil, especially for the short maturities (180 days), it is the unexpected part of changes in the policy rates which is driving the effects on swap rates (in the pre-crisis period), while the predicted part has hardly any impact.

4 In the Appendix we do not report the full detailed results since they are similar for most variables to those reported for the estimation with the observed policy rate in Table A.2.1 in Appendix 2. 
TABLE 6 EFFECT OF CBC COMMUNICATION ON DAILY CHANGES IN SWAP RATES,
WITH SURPRISE MONETARY POLICY RATE CHANGES

\begin{tabular}{|c|c|c|}
\hline $\begin{array}{l}\text { Swap rate changes } \\
\text { (maturity) }\end{array}$ & $\begin{array}{c}\text { Pre-crisis: } \\
\text { May 24, 2005 - September 12, } 2008\end{array}$ & $\begin{array}{c}\text { Post-crisis: } \\
\text { February 2, } 2009 \text { - November 3, } \\
2014\end{array}$ \\
\hline 180 days & $0.021 * * *$ & 0.0016 \\
\hline 360 days & $0.029 * * *$ & 0.0022 \\
\hline
\end{tabular}

Daily close minus previous day close. The COM dummy for communication has a FIVE-pronged classification as very expansionary $(-2)$, expansionary $(-1)$, neutral $(0)$, contractionary $(+1)$, and very contractionary $(+2)$. Component-GARCH estimation with Student-t Distribution. This corresponds to the estimation of equation (1) jointly with (2) and (3). ***significant at the $1 \%(* * 5 \% ; * 10 \%)$ on the basis of the Z-statistics.

\section{CONCLUSIONS}

This paper provides evidence on the ability of the Central Bank of Chile to affect the market interest rate futures and, in particular, the swap rate markets. We differentiate between deeds, i.e. changes in the Monetary Policy Rate, and words, i.e. written statements. For the latter, we collect information on speeches and summaries of Chile's Monetary Policy Committee, using data collected from 2005 until 2014. We, then, analyze separately the effects on the mean changes and on the short- or long-run volatility of the swap rates.

Our results show that from May 2005 to September 2008 -the pre-crisis period-, swap rates reacted mainly to words: they increased (decreased) following a contractionary (expansionary) piece of communication. In that period, the reaction of swap rates to deeds (i.e. to changes in the official rate) was not statistically significant.

This study also shows that after the global financial crisis, the response of swap rates to deeds and words changed in a substantial way. In the years after 2008, increases (decreases) in the MPR drove the swap rate up (down), as expected. In fact, monetary policy decisions, measured by their impact on swap rates, have gained prominence over the communication itself.

In addition to the results for changes in market rates (i.e. on the mean of interest rates) $\mathrm{CBC}$ communication impacts the volatility of swap markets and this impact is positive, which means that the $\mathrm{CBC}$ conveys information that markets perceive as relevant. However this impact is always temporary and is significant only in the pre-crisis period, confirming the finding that, in the post-crisis period, the $\mathrm{CBC}$ communication became less noisy.

Therefore in the case of Chile, evidence shows that, in the post crisis period, the swap market has reacted less than pre-crisis to the $\mathrm{CBC}$ communication, both in 
terms of the mean changes and the volatility of the rates, which probably reflects a more neutral or less noisy monetary policy communication. This trend is different from what has been observed in developed economies, where words have become more relevant. However in Chile the decreased importance of communication in the post-crisis period may reflect the fact that market participants have learned to understand the economic situation and its implication for monetary policy decisions, making them able to anticipate the changes in $\mathrm{CBC}$ communication. This anticipation is reflected in changes in the swap rates prior to the monetary policy announcement and almost no change in swap rates once the $\mathrm{CBC}$ statement is made available to the public. To provide support to this hypothesis would require incorporating surprises in $\mathrm{CBC}$ communication, which could be explored in future work. 


\title{
APPENDIX 1
}

\section{DESCRIPTIVE STATISTICS AND UNIT-ROOT TESTS}

\author{
TABLE A1
}

DESCRIPTIVE STATISTICS ON SWAP RATE CHANGES

\begin{tabular}{|l|c|c|}
\hline $\begin{array}{l}\text { Swap rate change } \\
\text { (maturity) }\end{array}$ & $\begin{array}{c}\text { May 24, 2005- } \\
\text { September 12, 2008 }\end{array}$ & $\begin{array}{c}\text { February 2, 2009- } \\
\text { November 3, 2014 }\end{array}$ \\
\hline 180 days & & \\
Mean & 0.006 & -0.001 \\
Std. dev & 0.049 & 0.046 \\
Skewness & -0.087 & -1.34 \\
Kurtosis & 9.77 & 25.5 \\
\hline 360 days & & \\
Mean & 0.057 & -0.0009 \\
Std. dev & 0.059 & 0.052 \\
Skewness & -0.303 & -0.793 \\
Kurtosis & 6.91 & 12.64 \\
\hline
\end{tabular}

\section{TABLE A2}

\section{UNIT-ROOT TESTS}

\begin{tabular}{|l|c|c|}
\hline $\begin{array}{l}\text { Elliott-Rottenberg-Stock } \\
\text { DF-GLS Test stat }\end{array}$ & $\begin{array}{c}\text { May 24, 2005 - } \\
\text { September 12, 2008 }\end{array}$ & $\begin{array}{c}\text { February 2, 2009- } \\
\text { November 3, 2014 }\end{array}$ \\
\hline $\begin{array}{l}\text { Swap rate } \\
\text { (maturity) } \\
180\end{array}$ & & \\
360 & 82.05 & 87.3 \\
\hline Swap rate change & 49.65 & 38.7 \\
(maturity) & & \\
180 & 0.37 & 0.72 \\
360 & 0.11 & 0.64 \\
\hline
\end{tabular}

With constant and trend. Null hypothesis: series has a unit root (Elliott, Rothenberg and Stock, 1996). DF-GLS statistics critical values are: $-3.48(1 \%),-2.89(5 \%),-2.57(10 \%)$. 


\section{APPENDIX 2}

\section{DETAILED ESTIMATION RESULTS}

\section{A. Effect of communication on mean}

TABLE A.2.1

SWAP RATE CHANGE WITH OBSERVED CHANGE IN MPR (AND COM IN MEAN EQUATION)

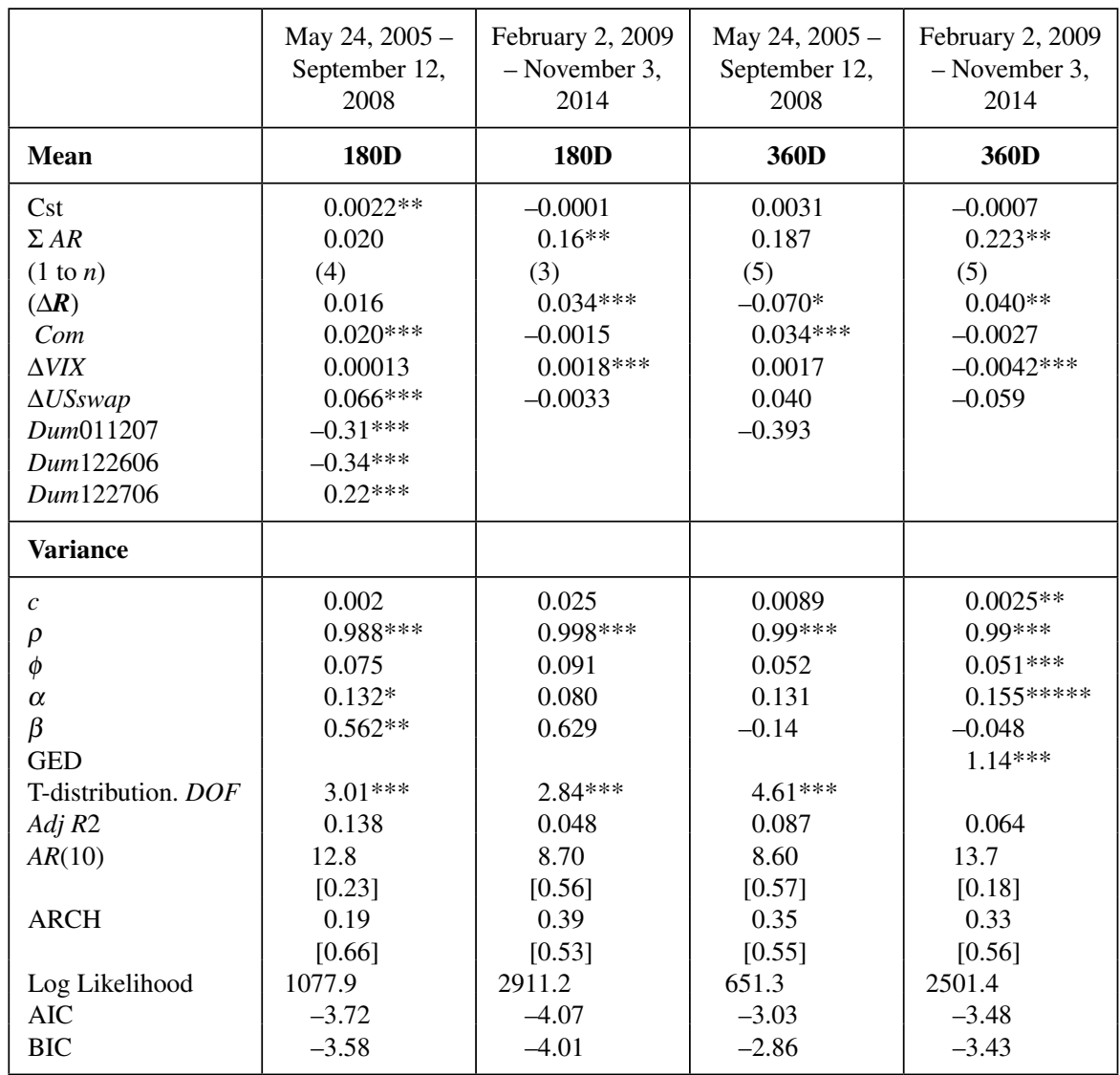

Interest rate 180 and 360 day swap rates: Daily close minus previous day close. The observed policy rate (MPR) is included in the mean equation. C-GARCH estimation with Student-t Distribution. This corresponds to the estimation of equation (1) jointly with (2) and (3). Parameters $\mu$ and $\lambda$ are constrained to zero. *** Z-statistic, significant at $1 \%$ level (** 5\%; * 10\%). [P-value]. 


\section{B. Effect of communication on volatility}

\section{TABLE A.2.2}

\section{SWAP RATE CHANGE WITH OBSERVED CHANGE IN MPR (AND ACOM IN VARIANCE EQUATION)}

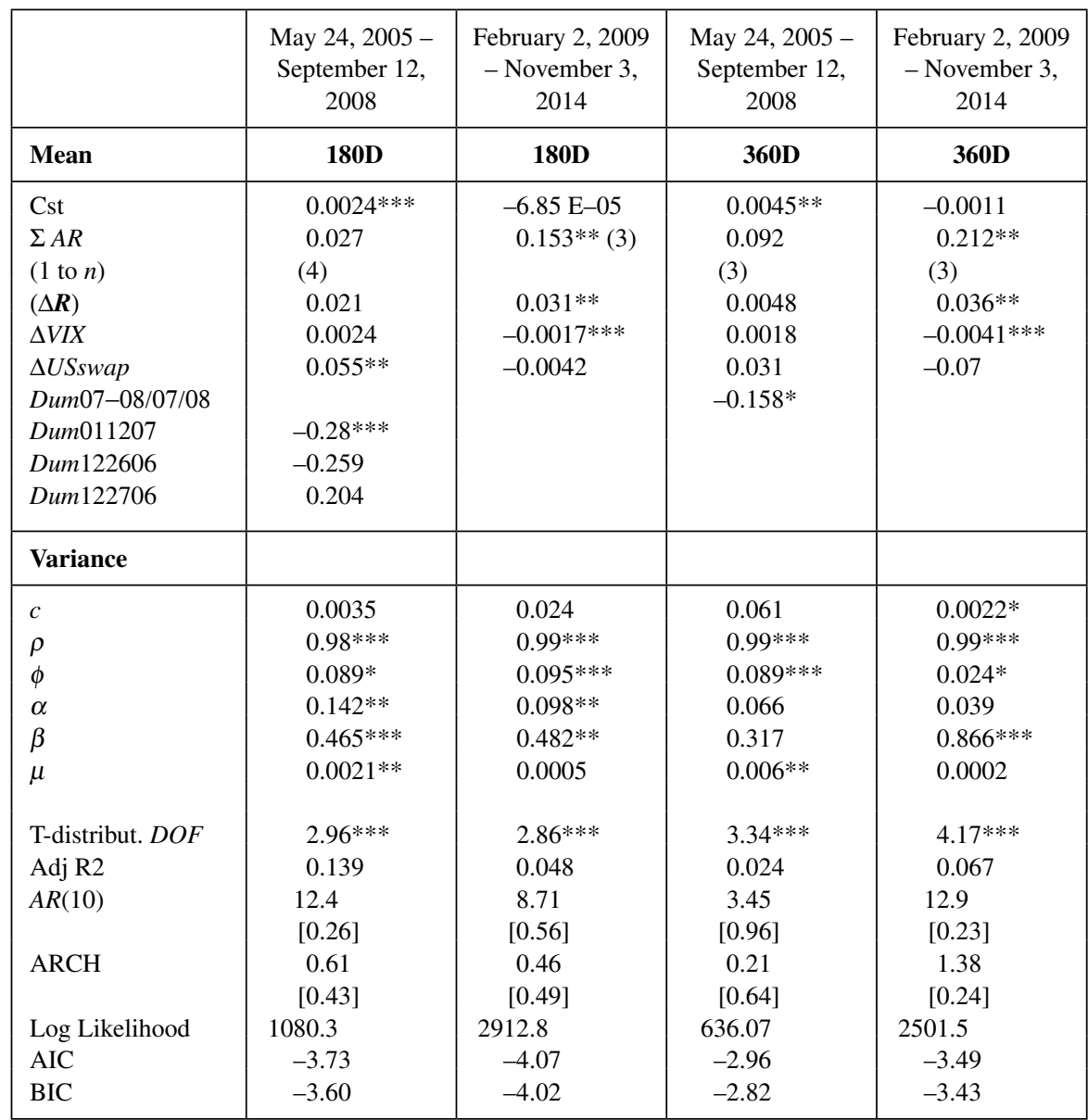

Interest rate 180 and 360 day swap rates: Daily close minus previous day close. C-GARCH estimation with Student-t distribution. This corresponds to equation (1), estimated together with equation (2), and (3) where $a_{3}$ and $\lambda$ are constrained to zero. $* * *$ Z-statistic significant at $1 \%$ level (** 5\%; * 10\%). [P-value]. 


\section{REFERENCES}

CESPEDES, L.F., and C. SOTO (2006). "Régimen de Metas de Inflación y Credibilidad de la Política Monetaria en Chile", Revista Economía Chilena 9 (3), Banco Central de Chile, December.

CONNOLLY, E. and M. KOHLER (2004). "News and Interest Rate Expectations: A Study of Six Central Banks" in The Future of Inflation Targeting, eds. C. Kent and S. Guttman. Sydney: Reserve Bank of Australia, pp. 108-134.

DE GREGORIO, J. (2008). “Transparencia y Comunicaciones en la Banca Central Moderna”, Documentos de Política Económica 25, Banco Central de Chile, July.

DING, Z. and C.W.J. GRANGER (1996). "Modelling Volatility Persistence of Speculative Returns: A New Approach", Journal of Econometrics 73, pp. 185-215.

EHRMANN, M. and M. FRATZSCHER (2007). "Communication by Central Bank Committee Members: Different Strategies, Same Effectiveness?”, Journal of Money, Credit, and Banking 39 (2-3), pp. 509-541.

ELLIOTT, C., T.J. ROTHENBERG and J.H. STOCK (1996). "Efficient Tests for an Autoregressive Unit Root", Econometrica 64, pp. 813-836.

ENGLE, R.F. and G.G.J. LEE (1999). "A Long-Run and Short-Run Component Model of Stock Return Volatility" in Cointegration, Causality, and Forecasting, ed. by Engle, and White. Oxford University Press.

FLEMING, J.M. and E.M. REMOLONA (1999). "Price Formation and Liquidity in the U.S Treasury Market: The Response to Public Information", Journal of Finance 54 (5), pp. 1901-1915.

GARCIA-HERRERO, A., E. GIRARDIN and E. DOS SANTOS (2015). "Follow what I do, and also what I say: monetary policy impact on Brazil's financial markets", BBVA, Economic research department, Working Paper, 15/12, April.

GERAATS, P. (2002). "Central Bank Transparency”, Economic Journal 112, pp. 532-565.

KOHN, D.L. and B. SACK (2004). "Central Bank Talk: Does it Matter and Why?" in Macroeconomics, Monetary Policy, and Financial Stability, Ottawa: Bank of Canada, pp. 175-206.

LARRAIN, M. (2007). "Sorpresas de Política Monetaria y la Curva de Rendimiento en Chile", Revista Economía Chilena 10 (1), Banco Central de Chile, April.

MEYER de P, J. (2006). "Impacto de las Sorpresas Económicas en el Rendimiento de los Bonos del Banco Central de Chile", Revista Economía Chilena 9 (2), Banco Central de Chile, August.

REEVES, R. and M. SAWICKI (2007). "Do Financial Markets React to Bank of England Communication?", European Journal of Political Economy 23 (1), pp. 207-227.

ROSA, C. and G. VEGA (2007). "On the Consistency and Effectiveness of Central Bank Communication: Evidence from the ECB”, European Journal of Political Economy 23 (1), pp. 146-175.

VERGARA, R. (2014). "Estrategias de Comunicación y Efectividad de la Política Monetaria”, Documentos de Política Económica 50, Banco Central de Chile, June. 
